\title{
Workplace spirituality and job satisfaction toward job performance: The mediation role of work- place deviant behavior and workplace passion
}

\author{
Anis Eliyana ${ }^{a^{*}}$ and Ahmad Rizki Sridadia
}

${ }^{a}$ Universitas Airlangga, Indonesia

\begin{tabular}{l}
\hline C H R O N I C L E \\
\hline Article history: \\
Received: February 16, 2020 \\
Received in revised format: \\
March 272020 \\
Accepted: March 29, 2020 \\
Available online: \\
March 31, 2020 \\
\hline Keywords: \\
Workplace spirituality \\
Job satisfaction \\
Job Performance \\
Workplace Deviant Behavior \\
Workplace passion \\
Employee well-being
\end{tabular}

\section{A B S T R A C T}

This research is intended to test the connections between the influence of Workplace Spirituality and Job Satisfaction on job performance with Workplace Deviant Behavior and Workplace Passion as a mediation. The data collected were from questionnaires distributed with an accidental sampling technique. Statistic Experimental Tool, SEM (Structural equation model) was used to analyze the data. The results of this research show that there was a significantly negative influence of Workplace Spirituality and Workplace Deviant Behavior on performance. Likewise, there was also a significantly negative influence of Workplace Deviant Behavior on the performance. Furthermore, work passion weakens the interaction between them.

\section{Introduction}

C 2020 by the authors; licensee Growing Science, Canada

Workplace spirituality is a concept discussed by some researchers from the twenty-one century (Milliman et al., 2003). Managing workplace spirituality properly can control individual behavior in the workplace. Therefore, according to James et al. in Case and Gosling (2010), if an employee can control his or her behavior through spirituality in workplace, he or she can improve the performance. According to Santis et al. (2018) as cited in Eliyana et al. (2019) work performance is a person's ability to carry out activities that contribute to the development of the organization's technical core. Job satisfaction can also improve employee's performance. Job satisfaction is identified as a pleasure or displeasure feeling of employee in working. Based on Judge, et al. (2001), there is a theoretical and empirical study saying that job satisfaction is a source of employee's performance. An employee who is satisfied with the job will work well. Further, in line with this idea, according to Robbins and Judge (2015, p.110), an employee who is satisfied with the job becomes a productive worker. In a research by Ahmad and Omar (2014), it was found out that workplace spirituality and job satisfaction can decrease deviant behavior in workplace (hereinafter will be mentioned as WDB). Generally, WDB happens in various organizational levels, this behavior includes unpunctuality in working, taking a break longer than it should be, spending working time for personal reasons, using inappropriate and different standards and procedures in working, and using working facilities for personal matters (Eliyana, 2015). In general, WDB triggers a threat of employee's morality in organizational context and individual context. Previous research also found that there was an influence of WDB to an employee and an organization (Srivastava, 2013). The influence of WDB to employees include decreasing performance, motivation, commitment to work, and productivity in working. While in the level of organization, the influence of WDB will clearly be seen in the efficiency, effectiveness, and productivity of the organization.

* Corresponding author.

E-mail address: anis.eliyana@feb.unair.ac.id (A. Eliyana) 
Another study found that there was a significant influence of WDB to performance (Muafi, 2011). An employee with high level of WDB has low level of performance. While an employee with low level of WDB has high level of performance. Another interesting finding is by Zigarmi et al. (2011), who found out that Workplace Passion Behavior (hereinafter will be mentioned as WPB) became a moderator of WDB influence to employees' performance (Zigarmi et al., 2011). Srivasta in Eliyana's (2015) stated that WPB is an individual consistency, in which a positive emotional condition gives meaning to the humanitarian welfare. Employees who have WPB create disciplined, productive, and result-oriented behaviors. When an employee has passion to a job, he or she will show the capabilities that the company needs. It will then create productive, energized, and loyal employees and at the same time become a valuable asset for the organization. In contrast, apathetic employees give financial burdens to the organization and break the morale. As a result, they decrease productivity and morale. This apathetic behavior may sometimes lead to workplace deviant behaviors. Based on the reason above, this research intends to investigate the influence of workplace spirituality and job satisfaction to job performance with workplace deviant behavior and workplace passion as the mediation. The sample is the government officers at all sub-district government offices in Surabaya. The reason of choosing government officers in Surabaya is that Surabaya administration is well known for maintaining employees' disciplines without exceptions. Having affairs, misusing position and professional job, and conducting money laundry are some examples of deviant behaviors that are subjected to penalties in Surabaya government office. Deviant behaviors are considered serious violation since the main job of government officers at sub-districts is giving optimal service to people's needs based on ethics and social norms as stated in the Government Regulations number 53 in 2010 which is developed from the Government Regulation number 30 in 1980.

\section{Concept Framework and Hypotheses}

Terminology of workplace spirituality is originally from normative assumption, in which employees bring spirituality to workplace and there is a need of spirituality for the employees in the workplace. Employees' need of spirituality cannot be separated from workplace, as stated by Duchon and Plowman in Case and Gosling (2010). Important dimension from spirituality at workplace is an opinion that employees have a spiritual need (that is spiritual life) because they have physical, emotional, and cognitive needs; and these needs will not be left behind at home when they come to the workplace. According to James, Miles, and Mullins in Case and Gosling (2010), Workplace spirituality should be managed properly, because if it is managed properly, this will be a way in working with individuals to control their behaviors at the workplace. In such a way that if an employee can control his or her behaviors through workplace spirituality then he or she can improve his or her performance.

H1. Workplace spirituality has significant influence on job performance.

H2. Workplace spirituality has significant influence on Work Deviant Behavior.

Robbins (2001, p. 24) explains that job satisfaction is a common behavior in a person's workplace, as he or she should get either a quantity of work load or reward. Some studies mention that emotional intelligence has significant positive effect on job satisfaction, one of them is by Chiva and Alegre (2008). Furthermore, other theories mention that naturally an individual can have a feeling of satisfaction or dissatisfaction with a job, as stated by Locke (in Luthans, 1998), job satisfaction was an emotional condition which was a pleasure created from a person's judgment of that job or experience. Job satisfaction is an emotional and cognitive feeling of an employee toward the judgment of the internal and external parts of the job. In line with this idea, as stated by Tella et al. (2007), job satisfaction was determined by salary earned, the job itself, colleagues, controls from supervisors, promotion chances, and common conditions in the working environment. Generally, employees with high level of job satisfaction seem to have positive behaviors, and dissatisfied employees with the job seem to show negative behaviors in working (Lumley et al., 2011; Robbins, 1993, p. 97).

H3. Job Satisfaction has significant influence on job performance.

H4. Job Satisfaction has significant influence on Work Deviant Behavior.

Workplace deviant behavior (WDB) or deviant behavior of an employee commonly exists in various and different levels of organizations in the world. Various kinds of WDB for instance: unpunctuality to the office, taking longer breaks, spending working time for personal needs, using working facilities for personal matters, marking-up organizational budgets, showing unfair attitudes as leaders. For leaders in an organization, socializing information which is not appropriate from the original sources is also an example of deviant behavior. WDB can be an emotional respond that comes from a person who experiences frustration because of the job. Previously, Bennett and Robinson in Srivastava's (2013) conducted a study for measuring job dissatisfaction related to the deviant behavior in working. When an employee is dissatisfied with the job, he or she will show the deviant behaviors in working that can decrease working performance, create lack of communication, fail in achieving high targets, and have low level of productivity.

H5. Work Deviant Behavior has significant influence on job performance. 
The definition of Work Passion Behavior (WPB) is an individual consistency, in which a positive emotional condition gives meaning to the humanitarian welfare. Employees who have WPB create disciplinary, productive, and result-oriented behaviors. When an employee has passion in a job, he or she will show his or her capabilities that the company needs. The employees' passion in the job will create productive, energized, and loyal employees under a certain organization, and at the same time, they become valuable assets for the organization. In contrast, apathetic employees give financial burdens to the organization and break the moral. As a result, they decrease productivity and moral. Sometimes, apathetic behaviors will cause workplace deviant behaviors (Srivastava, 2013).

H6. Work Passion Behavior weakens the influence of Work Deviant Behavior to performance.

$\mathrm{H} 3$

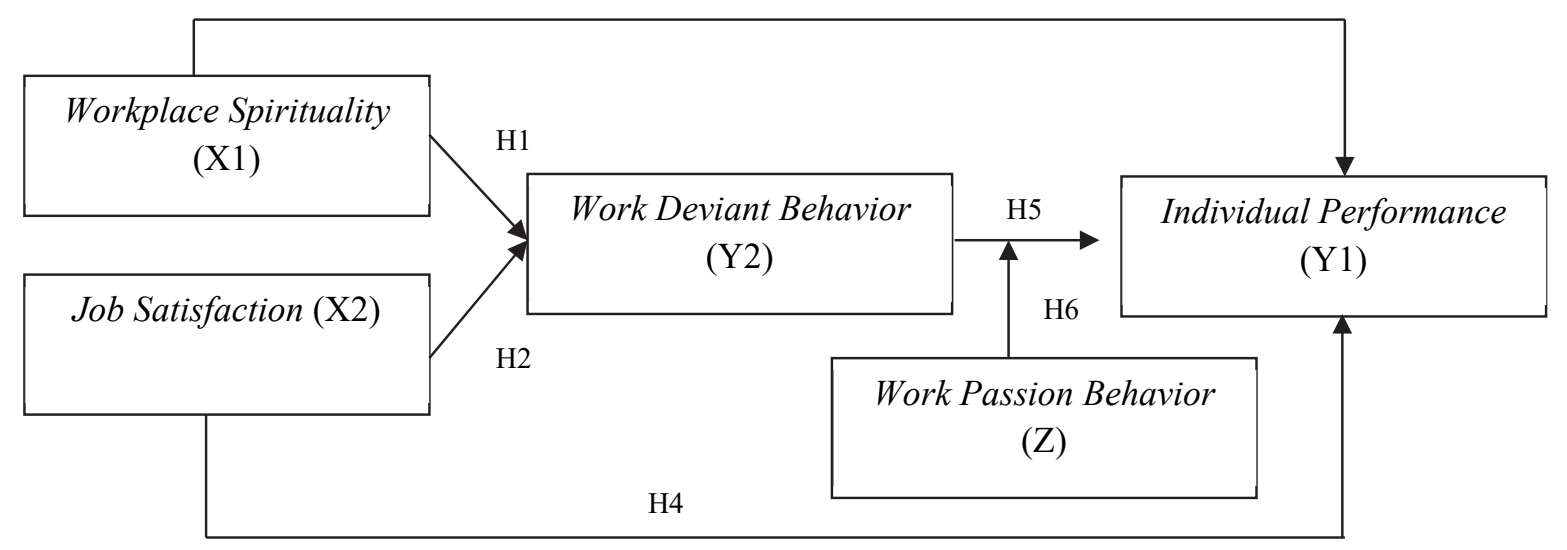

\section{Method}

Fig. 1. Research Framework

\subsection{Data Collection and Sample Characteristics}

This study with a quantitative approach uses sampling technique because the entire objects are not being observed. A research with a quantitative approach points out theory testing to measure research variables, using statistic procedures (Jogiyanto, 2005 , p. 5). This research is designed for explaining the influence between variables or the inter-connections between variables using hypothesis testing, or confirming the influence connections between variables; and is categorized as an Explanatory Research. In order to achieve the research purpose, the instruments used in data collection are questionnaires distributed with accidental sampling technique to Surabaya government officers. The population in this research is 891 government officers in sub-district offices in Surabaya. First respondents were 200 persons, however, after the revision of the sample, the respondents became 198 Surabaya government officers. The respondents were classified by genders in which the numbers were equal; female was in the percentage of $56 \%$ and the rest $44 \%$ were male. $54 \%$ of the respondents graduated from university and the rest $46 \%$ graduated from High School. The majority of the respondents with the percentage of $93 \%$, had been working for more than 10 years, $4 \%$ of the respondents had been working for 5-6 years, and the rest $4 \%$ had been working less than 5 years.

\subsubsection{Description of Respondents}

In this study, 200 respondents were divided into several characteristics according to gender, final education, and length of work. The clear description of each characteristics of the 200 respondents of the study can be seen in Table 1 .

Table 1

Characteristics of Respondents

\begin{tabular}{|c|c|c|c|}
\hline Characteristic & Classification & Total & Presentage \\
\hline \multirow[t]{2}{*}{ Gender } & Male & 89 & $44,50 \%$ \\
\hline & Female & 111 & $55,50 \%$ \\
\hline \multirow[t]{5}{*}{ Education } & High School & 92 & $46,00 \%$ \\
\hline & Diploma & 5 & $2,50 \%$ \\
\hline & Bachelor & 80 & $40,00 \%$ \\
\hline & Master Degree & 21 & $10,50 \%$ \\
\hline & Others & 2 & $1,00 \%$ \\
\hline \multirow[t]{3}{*}{ Work Period } & $\leq 5$ tahun & 7 & $3,50 \%$ \\
\hline & $>\overline{5}-10$ tahun & 7 & $3,50 \%$ \\
\hline & $>10$ tahun & 186 & $93,00 \%$ \\
\hline
\end{tabular}


Based on gender, respondents were dominated by women with 111 people or $55.5 \%$. According to education, most respondents were respondents with high school education with 92 people or $46 \%$. According to the length of work, respondents with more than 10 years of work were the dominant respondents with 186 or $93 \%$.

\subsubsection{Descriptive Statistics}

Descriptive assessment of each research variable is categorized based on the interval scale according to the average value. Calculation of interval scale is as follows:

$$
\text { Interval scale }=\frac{\text { Highest score }- \text { Lowest score }}{\text { Number of scales }}=\frac{5-1}{5}=0.8
$$

Rating categories for each variable according to the interval scale can be seen in Table 2 .

Table 2

Rating Category Based on Scale

\begin{tabular}{|c|c|c|c|c|c|}
\hline \multirow{2}{*}{ Variabel } & \multicolumn{5}{|c|}{ Assessment Interval Scale } \\
\hline & $1.00-1.80$ & $1.81-2.60$ & $2.61-3.40$ & $3.41-4.20$ & $4.21-5.00$ \\
\hline Job Satisfaction $\left(\mathrm{X}_{1}\right)$ & Very dissatisfied & Not satisfied & Quite satisfied & Satisfied & Very satisfied \\
\hline Work Place Spirituality $\left(\mathrm{X}_{2}\right)$ & Very low & Low & High enough & High & High enough \\
\hline Work Passion Behavior (Z) & Very low & Low & High enough & High & High enough \\
\hline Individual Performance $(\mathrm{Y})$ & Very bad & bad & Quite good & Well & Very good \\
\hline
\end{tabular}

Source: data processed

The results of the descriptive statistics for each research variable are shown in Table 3.

Table 3

Descriptive statistics

\begin{tabular}{ccc}
\hline Variable & Mean & \\
\hline Job Satisfaction $\left(\mathrm{X}_{1}\right)$ & 4.04 & \\
Work Place Spirituality $\left(\mathrm{X}_{2}\right)$ & 4.27 & 0.51 \\
Work Passion Behavior $(\mathrm{Z})$ & 4.17 & 0.45 \\
Individual Performance $(\mathrm{Y})$ & 4.22 & 0.43 \\
\hline
\end{tabular}

Source: data processed

Referring to Tables 2 and 3, an assessment of each variable can be carried out as follows:

1. The results of descriptive statistics for job satisfaction (X1) show an average value of 4.04 which indicates the condition that the average employee is satisfied with his job. The standard deviation value of 0.51 indicates a variation in the satisfaction level of $12.62 \%$ compared to the value overall average.

2. The results of descriptive statistics for work place spirituality (X2) show an average value of 4.27 which indicates the condition that the average employee has a very high working spirit. The standard deviation value of 0.45 indicates a variation in the level of work spirit of $10.54 \%$ compared to the overall average value.

3. Descriptive statistical results for work passion behavior $(Z)$ show an average value of 4.17 which indicates the condition that the average employee has a high passion for his work. The standard deviation value of 0.43 indicates a variation in employee's level of passion of $10.31 \%$ compared to the overall average value..

4. The results of descriptive statistics for individual performance (Y) show an average value of 4.22 which indicates the condition that the average employee has a very good performance. The standard deviation value of 0.40 indicates a variation in the level of employee performance by $9.48 \%$ compared to with the overall average value.

\subsubsection{Description of Job Satisfaction Variable $\left(X_{1}\right)$}

The description of job satisfaction variables can be seen in the average value for each indicator in Table 4.

Table 4

Description of Job Satisfaction Variable $\left(\mathrm{X}_{1}\right)$

\begin{tabular}{|c|c|c|c|}
\hline Item & Indicator & Average & Assessment \\
\hline $\mathrm{JS}_{1}$ & I feel satisfied with the salary that I receive every month & 4.06 & Satisfied \\
\hline $\mathrm{JS}_{2}$ & I feel satisfied with my job as an employee & 4.09 & Satisfied \\
\hline $\mathrm{JS}_{3}$ & I feel satisfied with my work colleagues & 4.03 & Satisfied \\
\hline $\mathrm{JS}_{4}$ & I feel satisfied with my supervisor's supervisory role & 4.09 & Satisfied \\
\hline $\mathrm{JS}_{5}$ & I am satisfied with the opportunity to increase the level given & 4.01 & Satisfied \\
\hline $\mathrm{JS}_{6}$ & I feel satisfied with the atmosphere of the work environment & 3.96 & Satisfied \\
\hline
\end{tabular}

Source: Appendix of Tabulation Results

Based on Table 4, it can be explained that the job satisfaction indicator which has the lowest rating is related to satisfaction with the atmosphere of the work environment, because it has the lowest average value, which is equal to 3.96. The indicators 
of job satisfaction that have the highest assessment are related to satisfaction with work as employees and satisfaction with supervisory supervisor roles, because it has the highest average value, which is equal to 4.09.

\subsubsection{Description of Work Place Spirituality Variable $\left(X_{2}\right)$}

The description of the work place spirituality variable can be seen in the average value for each indicator in Table 5 .

Table 5

Description of Work Place Spirituality Variable $\left(\mathrm{X}_{2}\right)$

\begin{tabular}{|c|c|c|c|}
\hline Item & Indicators & Average & Assessment \\
\hline $\mathrm{WS}_{1}$ & I try every day to come to work & 4,39 & Very high \\
\hline $\mathrm{WS}_{2}$ & I love my job & 4,33 & Very high \\
\hline $\mathrm{WS}_{3}$ & I work with enthusiasm & 4,38 & Very high \\
\hline $\mathrm{WS}_{4}$ & I feel my work has meaning for me & 4,32 & Very high \\
\hline $\mathrm{WS}_{5}$ & I feel that my work is important for my life & 4,29 & Very high \\
\hline $\mathrm{WS}_{6}$ & I feel my work is beneficial to others & 4,38 & Very high \\
\hline $\mathrm{WS}_{7}$ & I can freely express my opinion & 4,06 & Very high \\
\hline $\mathrm{WS}_{8}$ & I believe there is mutual support from colleagues & 4,20 & Very high \\
\hline $\mathrm{WS}_{9}$ & I can work with parties that have more positions & 4,14 & Very high \\
\hline $\mathrm{WS}_{10}$ & I can work with parties that are very meaningful & 4,26 & Very high \\
\hline $\mathrm{WS}_{11}$ & I want to achieve organizational goals together & 4,25 & Very high \\
\hline $\mathrm{WS}_{12}$ & I have a sense of being part of an organizational family & 4,30 & Very high \\
\hline $\mathrm{WS}_{13}$ & I have a strong sense of partisanship with the organization's vision and goals & 4,21 & Very high \\
\hline
\end{tabular}

Based on Table 5, it can be explained that workplace spirituality indicators that have the lowest judgment of freedom in expressing opinions, because they have the lowest average value, which is equal to 4.06. work, because it has the highest average value, which is equal to 4.39 .

\subsubsection{Description of Work Passion Behavior Variable (Z)}

Descriptions of work passion behavior variable can be seen in the average values for each indicator in Table 6 .

\section{Table 6}

Description of Work Passion Behavior Variable (Z)

\begin{tabular}{|c|c|c|c|}
\hline Item & Indicator & Average & Assessment \\
\hline $\mathrm{WP}_{1}$ & My work means a lot to me & 4,33 & Very high \\
\hline $\mathrm{WP}_{2}$ & I have full freedom in my work. & 4,12 & High \\
\hline $\mathrm{WP}_{3}$ & I can collaborate with colleagues in other parts if needed. & 4,19 & Very high \\
\hline $\mathrm{WP}_{4}$ & I get full justice treatment in my work. & 4,13 & High \\
\hline $\mathrm{WP}_{5}$ & I got my colleague's recognition of the results of my work. & 4,10 & High \\
\hline $\mathrm{WP}_{6}$ & $\begin{array}{l}\text { I have the opportunity to develop my skills through training / independent activities to increase professionalism } \\
\text { in my work }\end{array}$ & 4,14 & High \\
\hline $\mathrm{WP}_{7}$ & I have good relations with colleagues regarding the completion of my assignment. & 4,16 & High \\
\hline $\mathrm{WP}_{8}$ & I have a good relationship with the leadership regarding the completion of my assignment. & 4,16 & High \\
\hline
\end{tabular}

Source: Appendix of Tabulation Results

Based on Table 6, it can be explained that the work passion behavior indicator that has the lowest rating is related to the recognition of coworkers on the work results, because it has the lowest average value, which is 4.10 . with work that is very meaningful to employees, because it has the highest average value, which is equal to 4.33 .

\subsubsection{Description of Individual Performance Variable (Y)}

A description of individual performance variables can be seen in the average value for each indicator in Table 7 .

Table 7

Description of Individual Performance Variable (Y)

\begin{tabular}{|c|c|c|c|}
\hline Item & Indicator & Average & Assessment \\
\hline $\mathrm{IP}_{1}$ & Civil servants are able to do tasks according to the quality set by the office & 4.24 & Very high \\
\hline $\mathrm{IP}_{2}$ & Civil servants are able to complete tasks assigned to him in accordance with the time set & 4.30 & Very high \\
\hline $\mathrm{IP}_{3}$ & Civil servants are able to complete tasks according to the amount of work charged to him & 4.30 & Very high \\
\hline $\mathrm{IP}_{4}$ & Civil servants have a good service orientation & 4.26 & Very high \\
\hline $\mathrm{IP}_{5}$ & Civil servants have a high attitude of integrity & 4.14 & Very high \\
\hline $\mathrm{IP}_{6}$ & Civil servants have high commitment & 4.22 & Very high \\
\hline $\mathrm{IP}_{7}$ & Civil servants have a disciplined attitude & 4.23 & Very high \\
\hline $\mathrm{IP}_{8}$ & Civil servants are able to work with colleagues in the office & 4.23 & Very high \\
\hline $\mathrm{IP}_{9}$ & Civil servants have leadership skills & 4.10 & High \\
\hline
\end{tabular}

Source: Appendix of Tabulation Results 
Based on Table 7, it can be explained that the individual performance indicators that have the lowest rating are related to having a leadership spirit, because they have the lowest average value, which is equal to 4.10 . The individual performance indicators that have the highest rating are related to the ability to complete tasks that are charged in accordance with the time set and the ability to complete tasks according to the amount of work charged, because both have the highest average value, which is equal to 4.30 .

\subsection{Analysis Model and Hypothesis Testing}

\subsubsection{Validity and Reliability Testing}

Table 8

Validity and Reliability Testing Results

\begin{tabular}{|c|c|c|c|c|c|c|c|}
\hline Variable & Indicator & $\begin{array}{l}\text { Corrected } \\
\text { Item-Total } \\
\text { Correlation }\end{array}$ & $\begin{array}{l}\text { Cronbach } \\
\text { Alpha }\end{array}$ & Variable & Indicator & $\begin{array}{l}\text { Corrected } \\
\text { Item-Total } \\
\text { Correlation }\end{array}$ & $\begin{array}{c}\text { Cronbach } \\
\text { Alpha }\end{array}$ \\
\hline \multirow{6}{*}{$\begin{array}{l}\text { Job Satisfaction } \\
\qquad\left(\mathrm{X}_{1}\right)\end{array}$} & $\mathrm{JS}_{1}$ & 0.664 & \multirow{6}{*}{0.885} & \multirow{8}{*}{$\begin{array}{l}\text { Work Passion } \\
\text { Behavior }(\mathrm{Z})\end{array}$} & $\mathrm{WP}_{1}$ & 0.714 & \multirow[t]{8}{*}{0.902} \\
\hline & $\mathrm{JS}_{2}$ & 0.759 & & & $\mathrm{WP}_{2}$ & 0.716 & \\
\hline & $\mathrm{JS}_{3}$ & 0.701 & & & $\mathrm{WP}_{3}$ & 0.681 & \\
\hline & $\mathrm{JS}_{4}$ & 0.7 & & & $\mathrm{WP}_{4}$ & 0.697 & \\
\hline & $\mathrm{JS}_{5}$ & 0.685 & & & $\mathrm{WP}_{5}$ & 0.696 & \\
\hline & $\mathrm{JS}_{6}$ & 0.678 & & & $\mathrm{WP}_{6}$ & 0.678 & \\
\hline \multirow{11}{*}{$\begin{array}{c}\text { Workplace } \\
\text { Spirituality } \\
\qquad\left(\mathrm{X}_{2}\right)\end{array}$} & $\mathrm{WS}_{1}$ & 0.698 & \multirow{11}{*}{0.945} & & $\mathrm{WP}_{7}$ & 0.686 & \\
\hline & $\mathrm{WS}_{2}$ & 0.731 & & & $\mathrm{WP}_{8}$ & 0.678 & \\
\hline & $\mathrm{WS}_{3}$ & 0.743 & & \multirow{9}{*}{$\begin{array}{l}\text { Individual Per- } \\
\text { formance }(\mathrm{Y})\end{array}$} & $\mathrm{IP}_{1}$ & 0.669 & \multirow[t]{9}{*}{0.902} \\
\hline & $\mathrm{WS}_{4}$ & 0.729 & & & $\mathrm{IP}_{2}$ & 0.673 & \\
\hline & $\mathrm{WS}_{5}$ & 0.761 & & & $\mathrm{IP}_{3}$ & 0.669 & \\
\hline & $\mathrm{WS}_{6}$ & 0.714 & & & $\mathrm{IP}_{4}$ & 0.679 & \\
\hline & $\mathrm{WS}_{7}$ & 0.739 & & & $\mathrm{IP}_{5}$ & 0.667 & \\
\hline & $\mathrm{WS}_{8}$ & 0.735 & & & $\mathrm{IP}_{6}$ & 0.671 & \\
\hline & $\mathrm{WS}_{9}$ & 0.753 & & & $\mathrm{IP}_{7}$ & 0.681 & \\
\hline & $\mathrm{WS}_{10}$ & 0.73 & & & $\mathrm{IP}_{8}$ & 0.681 & \\
\hline & $\mathrm{WS}_{11}$ & 0.732 & & & $\mathrm{IP}_{9}$ & 0.681 & \\
\hline
\end{tabular}

Source: data processed

The test results show that the variables of job satisfaction (X1) had a value of Cronbach Alpha 0.885; workplace spirituality (X2) of 0.945; work passion behavior (Z) of 0.902; and individual performance (Y) of 0.902. Each had a Cronbach Alpha value that is greater than the cutoff value of 0.60, it can be stated reliably (Ghozali, 2001:46).

\subsubsection{Normality testing}

Table 9

The results of normality testing

\begin{tabular}{cc}
\hline & Unstandardized Residual \\
\hline $\mathrm{N}$ & 200 \\
Kolmogorov-Smirnov- $Z$ & 1,299 \\
Asymp.Sig.(2 tailed) & 0,069 \\
\hline
\end{tabular}

Source: data processed

Based on the results of normality testing, it can be seen that the Kolmogorov Smirnov statistical value obtained has a significance level greater than 0.05 , which is 0.069 , where the value is in accordance with the criteria that the distribution of data is normally distributed (Ghozali, 2001: 77).

\subsubsection{Deviation Test for the Multicollinearity Regression Model}

Table 10

Multicollinearity test

\begin{tabular}{|c|c|c|}
\hline Variable & VIF & Information \\
\hline $\mathrm{X}_{1}$ (Job Satisfaction) & 1.116 & There is no multicollinearity \\
\hline $\mathrm{X}_{2}$ (Workplace Spirituality) & 1.219 & There is no multicollinearity \\
\hline Z (Work Passion Behavior) & 1.190 & There is no multicollinearity \\
\hline $\mathrm{X}_{1} \mathrm{Z}$ (Interaction of Job Satisfaction and Work Passion Behavior) & 1.143 & There is no multicollinearity \\
\hline $\mathrm{X}_{2} \mathrm{Z}$ (Interaction of workplace spirituality and work passion behavior) & 1.127 & There is no multicollinearity \\
\hline
\end{tabular}

Source: Data processed 
According to the Table 10 shows that the overall VIF independent variable VIF less than the critical value of 10, so it can be concluded that in the regression model no symptoms multicollinearities.

\subsubsection{Deviation Test Regression Model Heterosidastity}

Table 11

Heterosidastity test

\begin{tabular}{|c|c|c|c|}
\hline Variable & Rank Spearman & Significance (Sig) & Information \\
\hline $\mathrm{X}_{1}$ (Job Satisfaction) & 0.040 & 0.575 & There is no heteroscedasticity \\
\hline $\mathrm{X}_{2}$ (Workplace Spirituality) & -0.081 & 0.257 & There is no heteroscedasticity \\
\hline Z (Work Passion Behavior) & 0.041 & 0.565 & There is no heteroscedasticity \\
\hline $\mathrm{X}_{1} \mathrm{Z}$ (Interaction of Job Satisfaction and Work Passion Behavior) & -0.123 & 0.084 & There is no heteroscedasticity \\
\hline $\mathrm{X}_{2} \mathrm{Z}$ (Interaction of workplace spirituality and work passion behavior) & -0.092 & 0.194 & There is no heteroscedasticity \\
\hline
\end{tabular}

Source: data processed

The test results show that none of the variables suffers from Heterosidastity effects, which appear in the Table 11, where the significance value of the Rank Spearman correlation coefficient for all independent variables is above the significance level (a) $5 \%$.

\subsubsection{Analysis Model}

The analysis technique used in this research is regression analysis moderation, with the dependent variable (Y) individual performance, and satisfaction independent job variable (X1) and workplace spirituality (X2), as well as a moderator variable work passion behavior $(Z)$.

Table 12

Results of Regression Analysis of Job Satisfaction (X) on Individual Performance (Y)

\begin{tabular}{|c|c|c|c|c|c|}
\hline Variable & Coefficient Regression (B) & Std. Error & Standardized Beta & $t$ count & Sig \\
\hline $\mathrm{X}_{1}$ (Job Satisfaction) & 0.225 & 0.053 & 0.282 & 4.263 & 0.000 \\
\hline $\mathrm{X}_{2}$ (Workplace spirituality) & 0.260 & 0.059 & 0.291 & 4.394 & 0.000 \\
\hline
\end{tabular}

Based on the results of the regression analysis the equation of the linear regression model was obtained as follows:

$$
\mathrm{Y}=2.206+0.225 \mathrm{X}_{1}+0.260 \mathrm{X}_{2}
$$

The results of t-test analysis with a significant level $(\alpha) 5 \%$ explain that:

1. Job satisfaction variable (X1) has a significant effect on individual performance variables (Y), because it has a probability level of error (sig.) 0,000 which is smaller than the significance level of $(\alpha) 0.05$.

2. Variable workplace spirituality (X2) has a significant effect on individual performance variables (Y), because it has a probability level of error (sig.) Of 0.000 which is smaller than the significance level of $(\alpha) 0.05$.

After the job satisfaction (X1) and workplace spirituality (X2) variables are proven to have a significant effect on individual performance $(\mathrm{Y})$, a moderating regression analysis model is developed to theoretically prove the effect of job satisfaction (X1), workplace spirituality (X2), moderator work passion variables behavior (Z), as well as the interaction variable between job satisfaction and work passion behavior $\left(\mathrm{X}_{1} \mathrm{Z}\right)$ and the interaction variable between workplace spirituality and work passion behavior $\left(\mathrm{X}_{2} \mathrm{Z}\right)$ on individual performance $(\mathrm{Y})$.

\section{Table 13}

Results of X1, X2, Z Regression Analysis, Interactions Between Job Satisfaction and Work Passion Behavior $\left(\mathrm{X}_{1} \mathrm{Z}\right)$, and Interactions Between Workplace Spirituality and Work Passion Behavior $\left(\mathrm{X}_{2} \mathrm{Z}\right)$ Against $\mathrm{Y}$

\begin{tabular}{|c|c|c|c|c|c|}
\hline Variable & $\begin{array}{c}\text { Coefficient } \\
\text { Regression (B) }\end{array}$ & Std. Error & $\begin{array}{c}\text { Standardized } \\
\text { Beta } \\
\end{array}$ & t count & Sig \\
\hline $\mathrm{X}_{1}($ Job Satisfaction $)$ & 0.199 & 0.050 & 0.250 & 3.963 & 0.000 \\
\hline $\mathrm{X}_{2}$ (Workplace Spirituality) & 0.166 & 0.059 & 0.186 & 2.823 & 0.005 \\
\hline Z (Work Passion Behavior) & 0.256 & 0.061 & 0.272 & 4.180 & 0.000 \\
\hline $\mathrm{X}_{1} \mathrm{Z}$ (Interactions Between Job Satisfaction and Work Passion Behavior) & 0.234 & 0.109 & 0.138 & 2.157 & 0.032 \\
\hline $\mathrm{X}_{2} \mathrm{Z}$ (Interactions Between Workplace Spirituality and Work Passion Behavior) & 0.006 & 0.122 & 0.003 & 0.047 & 0.962 \\
\hline
\end{tabular}

Based on the results of the moderating regression analysis, the equation of the multiple linear regression model is obtained as follows:

$$
\mathrm{Y}=4.212+0.199 \mathrm{X}_{1}+0.166 \mathrm{X}_{2}+0.256 \mathrm{Z}+0.234 \mathrm{X}_{1} \mathrm{Z}+0.006 \mathrm{X}_{2} \mathrm{Z}
$$

The results of the t-test analysis with a significant level of 5\% explain the following things: 
1. Job satisfaction variable (X1) has a positive significant effect on individual performance variables (Y), since it has a probability error value (sig) of 0,000 which is smaller than the significance level of 0.05 .

2. Variable workplace spirituality (X2) has a positive significant effect on individualized performance (Y) variables, since it has a probability error value ( $\mathrm{sig}$ ) of 0.005 which is smaller than the significance level of 0.05 .

3. Variable work passion behavior $(\mathrm{Z})$ has a significant positive effect on individual performance variables $(\mathrm{Y})$, since it has an error probability value (sig) of 0,000 smaller than the significance level of 0.05 .

4. Variable interactions between job satisfaction and passion behavior (X1Z) have a significant positive effect on individual performance variables (Y), since they have a probability error value (sig) of 0.032 which is smaller than the significance level of 0.05 .

5. Variable interaction between workplace spirituality and work passion behavior (X2Z) does not show a significant effect on individual performance variables (Y), since it has a probability error value (sig) of 0.962 which is smaller than the significance level of 0.05 .

In this study, the hypothesized variable as a moderator variable is work passion behavior $(\mathrm{Z})$, thus the equation of the regression model can be transformed as follows:

$$
Y=\alpha+\beta_{1} X_{1}+\beta_{2} X_{2}+\beta_{3} Z+\beta_{4} X_{1} Z+\beta_{5} X_{2} Z
$$

According to the moderation variable equation for the interaction between $\mathrm{X} 1$ and $\mathrm{Z}$ becomes:

For interactions between $\mathrm{X} 2$ and $\mathrm{Z}$ to be:

$$
\mathrm{Y}=\left(\beta_{1}+\beta_{4} Z\right) \mathrm{X}_{1}+\left(\beta_{3} \mathrm{Z}+\alpha\right)
$$

$$
Y=\left(\beta_{2}+\beta_{5} Z\right) X_{2}+\left(\beta_{3} Z+\alpha\right)
$$

Based on the results of regression analysis with moderating variables, the regression equation is obtained as follows:

$$
\mathrm{Y}=4.212+0.199 \mathrm{X}_{1}+0.166 \mathrm{X}_{2}+0.256 \mathrm{Z}+0.234 \mathrm{X}_{1} \mathrm{Z}+0.006 \mathrm{X}_{2} \mathrm{Z}
$$

The results of the descriptive statistical analysis of the centered data of each independent variable show the mean and standard deviation values as shown in Table 14.

Table 14

Descriptive Statistics Results (Centered Data)

\begin{tabular}{lcc}
\hline Variable & Mean & Standard Deviation \\
\hline Job Satisfaction $\left(\mathrm{X}_{1}\right)$ & 0 & 0.51 \\
Workplace Spirituality $\left(\mathrm{X}_{2}\right)$ & 0 & 0.45 \\
Work Passion Behavior $(\mathrm{Z})$ & 0 & 0.43 \\
\hline Source: data pros
\end{tabular}

Source: data processed

The independent variable is job satisfaction with the moderator variable work passion behavior (Z), then the equation used is as follows:

If;

$$
\mathrm{Y}=(0.199+0.234 \mathrm{Z}) \mathrm{X}_{1}+(0.256 \mathrm{Z}+4.212)
$$

$$
\begin{array}{lll}
\mathrm{Z}_{\text {Low }}=-0.43, & \text { then } & \mathrm{Y}=4.10+0.10 \mathrm{X}_{1} \\
\mathrm{Z}_{\text {Medium }}=0.00 & \text { then } & \mathrm{Y}=4.21+0.20 \mathrm{X}_{1} \\
\mathrm{Z}_{\text {High }}=0.43, & \text { then } & \mathrm{Y}=4.32+0.30 \mathrm{X}_{1}
\end{array}
$$

If expressed in the graph the impact of the moderator variable work passion behavior $(Z)$ on job satisfcation (X1) will appear as in Fig. 2. Fig. 2 shows the top regression line showing that if the work passion behavior $(Z)$ is high, then the regression line produced is $\mathrm{Y}=4.32+0.30 \mathrm{X} 1$. When the three regression lines are compared, it can be seen that when work passion behavior $(\mathrm{Z})$ is low, the effect of job satisfaction (X1) on individual performance (Y) is weaker than if the work passion behavior (Z) is high, resulting in individual performance $(Y)$ the lower one. If the work of passion behavior (Z) is high, the effect of job satisfaction (X1) on individual performance (Y) will be higher, so that the level of individual performance (Y) is higher when passion behavior is high, rather than during work passion behavior $(Z)$ low. This conclusion shows the existence of conditional factors, as an indication that work passion behavior $(Z)$ is a moderator variable.

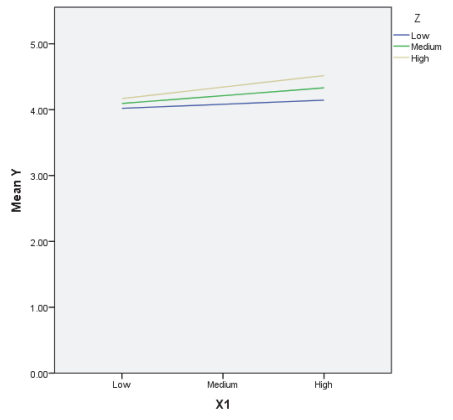

Fig. 2. Regression with Conditional Value Variable Work Passion Behavior (Z) for Job Satisfaction (X1)

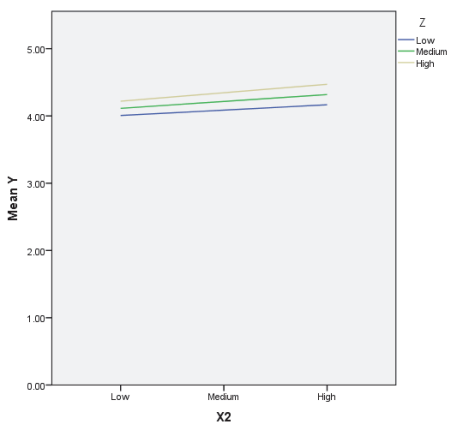

Fig. 3. Regression with Conditional Value Work Passion Behavior (Z) Over Workplace Spirituality (X2) 
The moderation equation that results from the work behavior passion variable $(Z)$ as a moderator variable is as follows:

1. If $Z_{\text {Low }}=-0.43, \quad$ then $Y=4.10+0.10 X_{1}$

2. If $Z_{\text {Medium }}=0.43 \quad$ then $Y=4.21+0.20 \mathrm{X}_{1}$

3. If $\mathrm{Z}_{\mathrm{High}}=0.43$, then $\mathrm{Y}=4.32+0.30 \mathrm{X}_{1}$

The condition of $Z_{M}$, showing the equation at work passion behavior $(Z)$ is at the average level, while the conditions of $Z L$ and $\mathrm{ZH}$ show at work passion behavior $(\mathrm{Z})$ is low and high, respectively. Because attention is focused on the strong influence of job satisfaction (X1) on individual performance (Y) at the time of low and high work passion behavior (Z), the analysis of the strength of moderation influences is seen in changes in the regression coefficient of job satisfaction (X1), the moderating effect is as follows:

1. Positive moderation effect $=(0.30-0.20) /(0.20)=50 \%$

2. Negative moderation effect $=(0.10-(0.20) /(0,20)=-50 \%$

Based on the results of the study show that high job satisfaction and high work passion behavior will result in higher individual performance. For independent workplace spirituality variables with work passion behavior (Z) moderator variables, the equations used are as follows:

$\mathrm{Y}=(0.166+0.006 \mathrm{Z}) \mathrm{X}_{2}+(0.256 \mathrm{Z}+4.212)$

If;

$\mathrm{Z}_{\text {Low }}=-0.43, \quad$ then $\quad \mathrm{Y}=4.10+0.163 \mathrm{X}_{2}$

$\mathrm{Z}_{\text {Medium }}=0, \quad$ then $\quad \mathrm{Y}=4.21+0.166 \mathrm{X}_{2}$

$\mathrm{Z}_{\mathrm{High}}=0.43, \quad$ then $\mathrm{Y}=4.32+0.169 \mathrm{X}_{2}$

As stated in the graph, the impact of the moderator variable work passion behavior (Z) on workplace spirituality (X2) has appeared in Fig. 3. The figure shows the top regression line indicating that if the work passion behavior $(\mathrm{Z})$ is high, the regression line produced is $\mathrm{Y}=4.32+0.169 \mathrm{X} 2$. If the three regression lines are compared, it can be seen that during the work of passion behavior $(\mathrm{Z})$ is low, the effect of workplace spirituality $(\mathrm{X} 2)$ on individual performance (Y) is weaker than if the work passion behavior $(\mathrm{Z})$ is high, resulting in individual performance $(\mathrm{Y})$ the lower one. If the work passion behavior $(\mathrm{Z})$ is high, the effect of workplace spirituality (X2) on individual performance (Y) will be higher, so that the level of individual performance $(\mathrm{Y})$ is higher when passion behavior is high, than during work passion behavior (Z) low. This conclusion shows the existence of conditional factors, as an indication that work passion behavior $(Z)$ is a moderator variable. The moderation equation that results from the work behavior passion variable $(Z)$ as a moderator variable is:

1. If $Z_{\text {Low }}=-0.43$, then $Y=4.10+0.163 X_{2}$

2. If $\mathrm{Z}_{\text {Medium }}=0.43$ then $\mathrm{Y}=4.21+0.166 \mathrm{X}_{2}$

3. If $\mathrm{Z}_{\mathrm{High}}=0.43$, then $\mathrm{Y}=4.32+0.169 \mathrm{X}_{2}$

The condition of $Z_{M}$, showing the equation at work passion behavior $(Z)$ is at the average level, while the condition $Z L$ and $\mathrm{ZH}$ show at work passion behavior $(\mathrm{Z})$ is low and high, respectively. Since attention is focused on the strong influence of workplace spirituality (X2) on individual performance (Y) at the time of low and high work passion behavior (Z), respectilvey the analysis of the strength of moderation influences is seen in changes in workplace spirituality (X2) regression coefficient, so that the magnitude of influence the moderating effect is as follows:

1. Positive moderation effect $=(0.169-0.166) /(0.166)=1,81 \%$

2. Negative moderation effect $=(0.163-(0.166) /(0.166)=-1.81 \%$

The results show that the interaction between workplace spirituality and work passion behavior (X2Z) did not have a significant effect on individual performance (Y), based on the results of the moderating effect.

\section{Discussion and Result}

Exogenous and endogenous constructs of all latent variables in this research are measured using many items or indicators. Workplace spirituality is measured using 13 indicators from Ashmos and Duchon's (2000). Job Satisfaction is measured using 6 indicators, referred from Luthans' (2008, pp. 142-144). 13 Indicators are used to measure WDB (Work Deviant Behavior), adopted from Bennet and Robinson's (2000). WPB (Work Passion Behavior) is measured using 8 indicators referred from Zigarmi's et al. (2011), whereas, IP (Individual Performance) is measured using 9 indicators. The respond of each indicator is in the form of scoring according to Likert 5 points of measuring scale (1-5) in which the range is that $5=$ strongly agree and $1=$ strongly disagree. Confirmation factor analysis being conducted is for measuring the dimensions that create construct/ latent variables in the research model. The analysis phases of the exogenous and endogenous construct confirmation factors 
have the purpose of testing uni-dimensionality of the dimensions that creates passion behavior $(\mathrm{Z})$, whereas, endogenous construct consists of workplace deviant behavior variable $\left(\mathrm{Y}_{2}\right)$ and individual performance $\left(\mathrm{Y}_{1}\right)$.

Table 15

The Results of Goodness of Fit (GOF) Testing and Compatibility Degrees of Confirmation Factor Analysis

\begin{tabular}{|c|c|c|c|}
\hline GOF Measurement & Compatibility Degree Target & Estimation Results & Compatibility Degrees \\
\hline Chi Square & Less than 1195.87 & $\mathrm{X}^{2}=1677.304$ & poor fit \\
\hline $\mathrm{P}$ & $(\mathrm{p}=0.05, \mathrm{df}=1117)$ & $\mathrm{P}=0.000$ & poor fit \\
\hline CMIN/DF & $<5$ & 1.502 & good fit \\
\hline GFI & $\mathrm{GFI} \geq 0.90$ & 0.740 & marginal fit \\
\hline RMSEA & $\mathrm{RMSEA} \leq 0.08$ & 0.050 & Good fit \\
\hline $\mathrm{P}($ close fit $)$ & $\mathrm{P} \geq 0 . \overline{0} 5$ & 0.434 & good fit \\
\hline ECVI & $\begin{array}{l}\text { Score which is less than ECVI saturated and inde- } \\
\text { pendence }\end{array}$ & $\begin{array}{l}\mathrm{D}^{*}=9.611 \\
\mathrm{~S}^{*}=12.437 \\
\mathrm{I}^{*}=36.906\end{array}$ & good fit \\
\hline TLI & $\mathrm{TLI} \geq 0.90$ & 0.902 & good fit \\
\hline AGFI & $\mathrm{AGFI} \geq 0.90$ & 0.715 & marginal fit \\
\hline IFI & IFI $\geq 0.90$ & 0.907 & good fit \\
\hline CFI & CFI $\geq 0.90$ & 0.907 & Good fit \\
\hline AIC & $\begin{array}{l}\text { Score which is less than AIC saturated and inde- } \\
\text { pendence }\end{array}$ & $\begin{array}{l}\mathrm{D}^{*}=1893.304 \\
\mathrm{~S}^{*}=2450.000 \\
\mathrm{I}^{*}=7270.521\end{array}$ & good fit \\
\hline CAIC & $\begin{array}{l}\text { Score which is less than CAIC saturated and inde- } \\
\text { pendence }\end{array}$ & $\begin{array}{l}D^{*}=2356.437 \\
S^{*}=7703.127 \\
I^{*}=7480.646\end{array}$ & good fit \\
\hline
\end{tabular}

Table 15 displays the results of Goodness of Fit Testing. Taken as a whole, it shows that the model fits in with the available data, because most of the testing results show good appropriateness levels. Each indicator fulfills the criteria of convergent validity dimension that creates variables of workplace spirituality $\left(\mathrm{X}_{1}\right)$, job satisfaction $\left(\mathrm{X}_{2}\right)$, workplace deviant behavior $\left(\mathrm{Y}_{2}\right)$, work passion behavior $(\mathrm{Z})$, and individual performance $(\mathrm{Y})$, because the score is more than 0.7 point of standardized loading factor. Beside observing the score of standardized loading factor, in the analysis of conformational condition factor, convergent validity can also be seen from average variance extracted (AVE) indicators of a set of latent constructs (Ghozali, 2014, p. 138). AVE is counted using the following formula:

Variance Extracted $=\Sigma$ Standardized Loading ${ }^{2} /\left(\Sigma\right.$ Standardized Loading ${ }^{2}+\Sigma \varepsilon j$

Notes:

Standardized loading

: Result of standardized regression weight for each indicator from the result of conformational factor testing

Measurement error $(\varepsilon j)$

: Result of 1 - quadrate of standardized loading

Based on the results of the analysis, it shows that the AVE score of each variable of workplace spirituality $\left(\mathrm{X}_{1}\right)$, job satisfaction $\left(\mathrm{X}_{2}\right)$, workplace deviant behavior $\left(\mathrm{Y}_{2}\right)$, work passion behavior $(\mathrm{Z})$, and individual performance $(\mathrm{Y})$ is $0.582 ; 0.566$; 0.558 ; 0.536; and 0.511 in which it is more than the score of cutoff 0.5 . It shows that there is a good convergent condition of each latent variable. Beside the measurement of convergent validity, the validity of latent variable indicator can also be ensured with discriminant validity. Discriminant validity measures until how far a construct is truly different from another construct (Ghozali, 2014, p. 141). The high score of discriminant validity proves that a construct is unique and it can capture the phenomena being measured. The way of testing is comparing the score of quadrate roots of AVE with the correlation score between constructs.

Table 16

Correlation between Construct and AVE Quadrate Root

\begin{tabular}{ccccc}
\hline X1 & X2 & Y2 & & \\
\hline Variable & $\mathbf{0 . 7 6 3}$ & & & \\
X1 & 0.349 & $\mathbf{0 . 7 5 2}$ & $\mathbf{0 . 7 4 7}$ & \\
Y2 & -0.376 & -0.363 & -0.232 & $\mathbf{0 . 7 3 2}$ \\
Z & 0.343 & 0.275 & -0.404 & 0.416 \\
Y1 & 0.437 & 0.419 & $\mathbf{0 . 7 1 5}$ & \\
\hline
\end{tabular}

Based on Table 16, it can be concluded that all latent variable constructs have higher score of AVE quadrate root than correlation between other constructs. This shows a good discriminant validity condition. To measure reliability, this research uses construct reliability. The formula to count construct reliability is as the following:

$$
\text { Construct Reliability }=(\Sigma \text { standardized loading })^{2} /(\Sigma \text { standardized loading })^{2}+\Sigma \varepsilon j
$$

Notes:

Standardized loading

Measurement error $(\varepsilon j)$
: The results of standardized regression weight for each indicator found from the result of conformational factor testing.

: $\quad$ Result from 1 - quadrate standardized loading 
The testing results in Table 2 show that construct reliability score of each variable of workplace spirituality $\left(\mathrm{X}_{1}\right)$, job satisfaction $\left(\mathrm{X}_{2}\right)$, workplace deviant behavior $\left(\mathrm{Y}_{2}\right)$, work passion behavior $(\mathrm{Z})$, and individual performance $\left(\mathrm{Y}_{1}\right)$ is 0.948 ; 0.887; 0.942 ; 0.902; and 0.904 , in which it is more than the score of cutoff 0.7 . This result brings to a conclusion that indicators measuring latent variable show the uni-dimensionality of the criteria.

\subsection{The results of Statistic Testing}

Analysis technique used to find out the influence between variables is Structural Equation Model (SEM) based on the theory and concept from the Analysis Program, $22^{\text {nd }}$ version of Moment Structure (AMOS). SEM is commonly seen as a combination between CFA (Confirmatory Factor Analysis) and regression analysis. Structural equation model is tested through two tests which are model appropriateness testing and causality significance testing in regression co-efficiency.

\subsection{Analysis of Structural Equation Model without Moderation}

Structural model analysis is to test the influence of workplace spirituality and job satisfaction to workplace deviant behavior and to test the influence of workplace spirituality, job satisfaction, workplace deviant behavior, and work passion behavior to individual performance, without the influence of the variable moderation of work passion behavior to see first whether deviant behavior significantly influences individual performance.

Table 17

The Result of Structural Model Analysis without Moderation

\begin{tabular}{cccccc}
\hline Influence & $\begin{array}{c}\text { Unstandardized Regression } \\
\text { Weight }\end{array}$ & S.E. & C.R. & P & $\begin{array}{c}\text { Standardized } \\
\text { Regression Weight }\end{array}$ \\
\hline $\mathrm{Y}_{2} \leftarrow \mathrm{X}_{1}$ & -0.318 & 0.085 & -3.743 & 0.000 & -0.284 \\
$\mathrm{Y}_{2} \leftarrow \mathrm{X}_{2}$ & -0.302 & 0.090 & -3.342 & 0.000 & -0.265 \\
$\mathrm{Y}_{1} \leftarrow \mathrm{X}_{1}$ & 0.166 & 0.062 & 2.686 & 0.007 & 0.208 \\
$\mathrm{Y}_{1} \leftarrow \mathrm{X}_{2}$ & 0.170 & 0.064 & 2.659 & 0.008 & 0.209 \\
$\mathrm{Y}_{1} \leftarrow \mathrm{Y}_{2}$ & -0.140 & 0.053 & -2.616 & 0.009 & -0.196 \\
$\mathrm{Y}_{1} \leftarrow \mathrm{Z}$ & 0.207 & 0.065 & 3.183 & 0.001 & 0.242 \\
\hline
\end{tabular}

Table 17 shows that all connections between variables are significant, as it is determined from the each score of P; the influence is not more than $(\alpha) 5 \%$ or 0.05 . The important point from the structural model analysis without moderation in this research is to find out the influence of workplace deviant behavior $\left(\mathrm{Y}_{2}\right)$ to individual performance $\left(\mathrm{Y}_{1}\right)$. The analysis results of workplace deviant behavior $\left(\mathrm{Y}_{2}\right)$ influence to individual performance are negatively significant, since the results show standardized regression weight scores at -0.196 and $(0.009<(\alpha) 5 \%$ or 0.05 significance.

\subsection{The Analysis of Structural Equation Model with Moderation}

After structural model analysis is done without moderation and it shows that workplace deviant behavior variable has significant influence to individual performance, so that, it can be continued with structural model anaysis with the variables of interaction between workplace deviant behavior and work passion behavior to see the influence of moderation of work passion behavior to the connection between workplace deviant behavior and individual performance. To do the structural model analysis with the influence of moderation, that interactional variable should be created first between workplace deviant behavior and work passion behavior $\left(\mathrm{Y}_{2} \mathrm{Z}\right)$. Because the interactional method will always include the appearance of multi-linearity at independent variables. One of the best solutions is to change the data into mean-centered format data before being analyzed (Ghozali, 2014, p. 244). Mean-centered is a transformation of raw data to become difference in score with that mean variable, in which the counting process is as follows:

$$
\text { Mean-centered }=\text { raw data }- \text { mean score }
$$

In this research, interaction variable is designed from the variables of workplace deviant behavior $\left(\mathrm{Y}_{2}\right)$ with work passion behavior, therefore, in those two variables, raw data of each indicator should be reduced with the score of the each mean. According to Ping (1995) in Ghozali's (2014, p. 244), it is stated that single indicator should be used as an indicator of a certain moderating variable. That single indicator is multiplication between exogenous latent variable indicator with moderation variable indicator. For example, if $X$ variable has indicators of $X_{1}$ and $X_{2}$, on the other hand, $Z$ variable has indicators of $Z_{1}$ and $Z_{2}$. Those interactional variable indicators $X Z$ are designed through counting $\left(X_{1}+X_{2}\right)\left(Z_{1}+Z_{2}\right)$. After the raw data, both are finished using mean-centered. To do the SEM Moderated Method (MSEM), there are two phases (Ghozali, 2014, p. 245):

1. In the first phase, estimation is made without inputting interactional variables, so that there are only model estimation with two exogenous variables. The result of this model output is used for counting the score of loading factor of interactional latent variable ( $\lambda$ interaction) and the score of error variance from interactional latent variable indicator is counted with the following formula:

$\lambda$ Interaction $=\left(\lambda X_{1}+\lambda X_{2}\right)\left(\lambda Z_{1}+\lambda Z_{2}\right)$

$\theta \mathrm{q}=\left(\lambda \mathrm{X}_{1}+\lambda \mathrm{X}_{2}\right)^{2} \operatorname{Var}(\mathrm{X})\left(\theta \mathrm{Z}_{1}+\theta \mathrm{Z}_{2}\right)+\left(\lambda \mathrm{Z}_{1}+\lambda \mathrm{Z}_{2}\right)^{2} \operatorname{Var}(\mathrm{Z})\left(\theta \mathrm{X}_{1}+\theta \mathrm{X}_{2}\right)+\left(\theta \mathrm{X}_{1}+\theta \mathrm{X}_{2}\right)\left(\theta \mathrm{Z}_{1}+\theta \mathrm{Z}_{2}\right)$

Notes: 
$\lambda$ interaction $=$ loading factor from interactional latent variable

$\theta \mathrm{q}=$ error variance from interactional latent variable indicator

Var $=$ Variance

2. In the second phase, after getting the score $\lambda$ of interaction and the score of $\Theta \mathrm{q}$, the scores can be inputted into a model with interactional latent variable. The counting result of interactional loading factor is used to set up parameter score or interactional loading, whereas, the counting result of error variance of interactional variable is used to set up error variance of interactional variable.

Anderson and Gerbing (1988), in (Cortina, et al., 2002) state that by creating parameter score to SEM is not a problem that causes bias estimation, unless latent variable is uni-dimension and non-multi-dimension (second order factor). In this research, interactional variable is designed from the variable of workplace deviant behavior $\left(\mathrm{Y}_{2}\right)$ and work passion behavior $(\mathrm{Z})$, so that the formula to count and to design $\lambda$ interaction and $\Theta q$ is as follows:

Table 18

Results of Counting $\lambda$ and $\theta \mathrm{q}$ Variable Interaction; Workplace Deviant Behavior and Work Passion Behavior $\left(\mathrm{Y}_{2} \mathrm{Z}\right)$

\begin{tabular}{|c|c|c|c|c|c|c|}
\hline Variables & Indicators & Std Loading & Error & Variance & $\lambda$ Interaction & $\theta \mathbf{q}$ \\
\hline \multirow{13}{*}{$\mathrm{Y}_{2}$} & $\mathrm{WDB}_{1}$ & 0.823 & 0.123 & \multirow[t]{13}{*}{0.258} & \multirow[t]{13}{*}{56.815} & \multirow[t]{13}{*}{42.812} \\
\hline & $\mathrm{WDB}_{2}$ & 0.744 & 0.164 & & & \\
\hline & $\mathrm{WDB}_{3}$ & 0.706 & 0.224 & & & \\
\hline & $\mathrm{WDB}_{4}$ & 0.825 & 0.118 & & & \\
\hline & $\mathrm{WDB}_{5}$ & 0.721 & 0.223 & & & \\
\hline & $\mathrm{WDB}_{6}$ & 0.754 & 0.134 & & & \\
\hline & $\mathrm{WDB}_{7}$ & 0.702 & 0.249 & & & \\
\hline & $\mathrm{WDB}_{8}$ & 0.746 & 0.132 & & & \\
\hline & $\mathrm{WDB}_{9}$ & 0.742 & 0.132 & & & \\
\hline & $\mathrm{WDB}_{10}$ & 0.727 & 0.142 & & & \\
\hline & $\mathrm{WDB}_{11}$ & 0.726 & 0.157 & & & \\
\hline & $\mathrm{WDB}_{12}$ & 0.731 & 0.147 & & & \\
\hline & WDB $_{13}$ & 0.755 & 0.137 & & & \\
\hline \multirow[t]{8}{*}{$\mathrm{Z}$} & $\mathrm{WP}_{1}$ & 0.749 & 0.126 & \multirow[t]{8}{*}{0.179} & & \\
\hline & $\mathrm{WP}_{2}$ & 0.759 & 0.127 & & & \\
\hline & $\mathrm{WP}_{3}$ & 0.721 & 0.113 & & & \\
\hline & $\mathrm{WP}_{4}$ & 0.760 & 0.115 & & & \\
\hline & $\mathrm{WP}_{5}$ & 0.739 & 0.134 & & & \\
\hline & $\mathrm{WP}_{6}$ & 0.704 & 0.196 & & & \\
\hline & $\mathrm{WP}_{7}$ & 0.720 & 0.146 & & & \\
\hline & $\mathrm{WP}_{8}$ & 0.704 & 0.182 & & & \\
\hline
\end{tabular}

Source: Data from the Results of Structural Analysis and CFA without moderation

Model estimation is executed by inputting interactional variables. The score of loading factors for interactional variables are constrained with 56.815 points, and the score of error variance for interactional variables are constrained with 42.812 points.

Table 19

Analysis Results of Structural Model with Moderation

\begin{tabular}{cccccc}
\hline Influence & $\begin{array}{c}\text { Unstandardized Regression } \\
\text { Weight }\end{array}$ & S.E. & C.R. & P & $\begin{array}{c}\text { Standardized Regres- } \\
\text { sion Weight }\end{array}$ \\
\hline $\mathrm{Y}_{2} \leftarrow \mathrm{X}_{1}$ & -0.318 & 0.079 & -4.028 & 0.000 & -0.313 \\
$\mathrm{Y}_{2} \leftarrow \mathrm{X}_{2}$ & -0.301 & 0.088 & -3.411 & 0.000 & -0.275 \\
$\mathrm{Y}_{1} \leftarrow \mathrm{X}_{1}$ & 0.188 & 0.062 & 3.033 & 0.002 & 0.268 \\
$\mathrm{Y}_{1} \leftarrow \mathrm{X}_{2}$ & 0.182 & 0.063 & 2.863 & 0.004 & 0.239 \\
$\mathrm{Y}_{1} \leftarrow \mathrm{Y}_{2}$ & -0.137 & 0.053 & -2.595 & 0.009 & -0.198 \\
$\mathrm{Y}_{1} \leftarrow \mathrm{Z}$ & 0.204 & 0.064 & 3.177 & 0.001 & 0.241 \\
$\mathrm{Y}_{1} \leftarrow \mathrm{Y}_{2} \mathrm{Z}$ & 0.148 & 0.029 & 5.148 & 0.000 & 0.408 \\
\hline
\end{tabular}

Direct influence to WDB (Workplace deviant behavior) is shown in Table 5 with the details, as follows:

- The influence of Workplace spirituality $\left(\mathrm{X}_{1}\right)$ to the Workplace deviant behavior $\left(\mathrm{Y}_{2}\right)$ is significantly negative, that is because it has got a score of Standardized Regression weight at -0.313 and the score of error probability $(p)$ is $0.000<(\alpha)$ 0.05 . It means that the more workplace spirituality $\left(\mathrm{X}_{1}\right)$ increases, the more workplace deviant behavior $\left(\mathrm{Y}_{2}\right)$ will decrease, as well as the score decreasing of the standardized regression weight. First hypothesis (H1) stating that workplace spirituality gives significant influence to work deviant behavior of Surabaya Government officers is accepted.

- The influence of job satisfaction $\left(\mathrm{X}_{2}\right)$ to workplace deviant behavior $\left(\mathrm{Y}_{2}\right)$ is negative, that is because it has got the score of standardized regression weight of -0.275 and the score of error probability $(\mathrm{p})$ is $0.000<(\alpha) 0.05$. It means that the more job satisfaction $\left(\mathrm{X}_{2}\right)$ increases, the more workplace deviant behavior $\left(\mathrm{Y}_{2}\right)$ decreases, as well as the score decreasing of the standardized regression weight. As a result, the second hypothesis (H2) stating that job satisfaction gives significant influence to work deviant behavior of Surabaya government officers is accepted. 
Direct influence to IP (individual Performance) is shown in Table 5 as follows:

- The influence of workplace spirituality $\left(\mathrm{X}_{1}\right)$ to individual performance $\left(\mathrm{Y}_{1}\right)$ is significantly positive, that is because it has got the score of standardized regression weight of 0.268 and the score of probability error $(p)$ is $0.002<(\alpha) 0.05$. It means that the more workplace spirituality $\left(\mathrm{X}_{1}\right)$ increases, the more individual performance will increase as well, in line with the score increasing of the standardized regression weight. And then, the third hypothesis stating that workplace spirituality gives significant influence to the performance of Surabaya government officers is accepted.

- The influence of Job Satisfaction $\left(\mathrm{X}_{2}\right)$ to individual performance $\left(\mathrm{Y}_{1}\right)$ is significantly positive, that is because the score of standardized regression weight is at 0.239 and the score of probability error $(p)$ is $0.004<(\alpha) 0.05$. It means that the more job satisfaction $\left(\mathrm{X}_{2}\right)$ increases, the more individual performance $\left(\mathrm{Y}_{1}\right)$ will increase as well, in line with the score increasing of the standardized regression weight. In this case, the fourth hypothesis stating that job satisfaction gives significant influence to the performance of Surabaya government officers is accepted.

- The influence of work deviant behavior $\left(\mathrm{Y}_{2}\right)$ to individual performance $\left(\mathrm{Y}_{1}\right)$ is negative, that is because it has got the score of standardized regression weight at 0.198 and the score of error probability(p) is $0.009<(\alpha) 0.05$. It means that the more workplace deviant behavior $\left(\mathrm{Y}_{2}\right)$ increases, the more individual performance will decrease, as well as the score decreasing of the standardized regression weight. After that, the fifth hypothesis (H5) stating that workplace deviant behavior gives significant influence to the performance of Surabaya government officers is accepted.

Moderation effect of WP (Work Passion behavior) to the influence of WDB to IP is explained in details as the followings:

- The influence of the interaction between workplace deviant behavior and work passion behavior ( $\left.\mathrm{Y}_{2} \mathrm{Z}\right)$ to individual performance $\left(\mathrm{Y}_{1}\right)$ is positive, that is because it has got the positive score of standardized regression weight at 0.408 . It means that the more interaction between workplace deviant behavior and work passion behavior $\left(\mathrm{Y}_{2} \mathrm{Z}\right)$ increases, the more individual performance $\left(\mathrm{Y}_{1}\right)$ will increase, as well as the score increasing of the standardized regression weight. The influence of the interaction between workplace deviant behavior and work passion behavior $\left(\mathrm{Y}_{2} \mathrm{Z}\right)$ to individual performance $\left(\mathrm{Y}_{1}\right)$ is significant, that is because it has got the score of error probability (p) at 0.000 which is less than the level of significance ( $\alpha$ ) $5 \%$ or 0.05 . It can be concluded that the interaction between workplace deviant behavior and work passion behavior $\left(\mathrm{Y}_{2} \mathrm{Z}\right)$ gives positively significant influence to individual performance $\left(\mathrm{Y}_{1}\right)$. Next, the sixth hypothesis stating that work passion behavior weakens the influence of work deviant behavior to the performance of Surabaya government officers is accepted.

The results of this research show how big the contribution of the influence of workplace spirituality $\left(\mathrm{X}_{1}\right)$ and job satisfaction $\left(\mathrm{X}_{2}\right)$ to workplace deviant behavior $\left(\mathrm{Y}_{2}\right)$ is, in which the score is 0.252 . It means that $25.2 \%$ of the workplace deviant behavior $\left(\mathrm{Y}_{2}\right)$ level is influenced by the level of workplace spirituality $\left(\mathrm{X}_{1}\right)$ and job satisfaction $\left(\mathrm{X}_{2}\right)$, whereas, the rest $74.8 \%$ is determined by other factors which are not being researched. It is likely that how big the contribution of the influence of workplace spirituality $\left(\mathrm{X}_{1}\right)$, job satisfaction $\left(\mathrm{X}_{2}\right)$, workplace deviant behavior $\left(\mathrm{Y}_{2}\right)$, work passion behavior $(\mathrm{Z})$ and the interaction between workplace deviant behavior and work passion behavior $\left(\mathrm{Y}_{2} \mathrm{Z}\right)$ to individual performance $\left(\mathrm{Y}_{1}\right)$ is at 0.379 points, in which $37.9 \%$ of the level of individual performance $\left(\mathrm{Y}_{1}\right)$ is influenced by the level of workplace spirituality $\left(\mathrm{X}_{1}\right)$, job satisfaction $\left(\mathrm{X}_{2}\right)$, workplace deviant behavior $\left(\mathrm{Y}_{2}\right)$, work passion behavior $(\mathrm{Z})$, and interaction between workplace deviant behavior with work passion behavior $\left(\mathrm{Y}_{2} \mathrm{Z}\right)$, whereas, the rest $62.1 \%$ is still determined by other factors which are not being researched.

\section{Discussion}

This research is intended to test the connections between the influence of Workplace spirituality and Job Satisfaction to the performance with Workplace deviant behavior and Workplace Passion as the mediation and conducted to government officers at all sub-district offices in Surabaya. The test shows that both workplace spirituality and job satisfaction have significant negative influence to WDB (Workplace deviant behavior). This issue is linier with the research by Bennett and Robinson in Srivastava's (2013) which measured working dissatisfaction connection to deviant behavior. When an employee is dissatisfied with the job, he or she will show the deviant behavior in the workplace. This idea is also linier to James, Miles, and Mullins in Case and Gosling (2010) stating that Workplace spirituality should be managed properly, because if workplace spirituality is managed properly, this can become a way in working of an individual to control individual behavior at the workplace. The influence of WDB to IP, based on the analysis results in this research, is significantly negative. In line with a research by O'Leary-Kelly, Griffin and Glew (1996) stated that employees with deviant behaviors will more probably quit the job, have problems with stress, productivity decreases, low level of morality, lose working hours, have low self-esteem, high level of fear, feel inconvenience at the workplace, and also feel uncomfortable. Whereas, the role of WP mediation in the interaction between WDB and IP is that it weakens connections of WDP influence to IP. Employees who have passion in working are persevering employees, having positive emotion, giving meaning to humanitarian welfare that is originally from cognitive and affective judgment of various jobs and organizational situations, creating consistent behaviors, and having constructive passion (Zigarmi et al., 2011). 


\section{Conclusion}

The results of this research are in line with the previous researches with the same topic. In this research, we have found out that there was a significant negative influence of workplace spirituality and job satisfaction to WDB. If an employee is satisfied with the job, the chance of having deviant behaviors is decreasing; further, the level of workplace spirituality is increasing. Besides, it is also found out that there is a significant negative influence connection in WDB to IP. Performance as a goal of an organization can be influenced by WDB, because of that, WDB should be considered and controlled to be minimized or erased. Significances of this research are that there is a finding that mediation effect of WP (Work Passion) can weaken WDP influence to IP. Previous researches focus more on the role of WP (Work Passion) directly. The results of this research can be contributed for Surabaya Government in managing sub-districts government officers. Beside finding the general outlook of government officers' conditions in Surabaya Sub-districts about working spirituality, job satisfaction, WDB, even WP, this research is to help deciding steps to respond the issue.

\section{References}

Ahmad, A. and Omar, Z. (2014). Reducing deviant behavior through workplace spirituality and job satisfaction. Asian Social Science, 10(19), 107-112.

Ashmos, D. P. and Duchon, D. (2000). Spirituality at work: A conceptualization and measure. Journal of Management Inquiry, 9(2), 2134-145.

Bennet, R. J., \& Robinson, S. L. (2000). Development of a measure of workplace deviance. Journal of Applied Psychology, 85(3), 349-360.

Case, P., \& Gosling, J. (2010). The spiritual organization: Critical reflections on the instrumentality of workplace spirituality. Journal of Management, Spirituality and Religion, 7(4), 257-282.

Chiva, R., \& Vidal, J. (2008). Emotional intelligence and job satisfaction: The role of organizational learning capability. Personnel Review, 37. 10.1108/00483480810906900.

Cortina, L. M., Lonsway, K. A., Magley, V. J., Freeman, L. V., Collinsworth, L. L., Hunter, M., et al. (2002). What's gender got to do with it? incivility in the Federal Court. Law and Social Inquiry, 27(2), 235-270.

Eliyana, A. (2015). Peran moderator workplace passion pada pengaruh workplace deviant behavior terhadap kepuasan kerja. Surabaya: Universitas Airlangga.

Eliyana, A., Ma'arif, S. and Muzakki. (2019). Job Satisfaction and Organizational Commitment Effect in the Transformational Leadership toward Employee Performance. European Research on Management and Business Economics, 25(3), 144-150. https://doi.org/10.1016/j.iedeen.2019.05.001

Ghozali, I. (2011). Aplikasi Analisis Multivariate dengan Program SPSS. Semarang: Badan Penerbit Universitas Diponegoro.

Ghozali, I. (2014). Partial Least Squares: Concepts, Methods, and Applications using WarpPLS4. Semarang: Badan Penerbit Universitas Diponegoro.

Jogiyanto, H. (2005). Analisis dan Desain Informasi: Pendekatan Terstruktur Teori dan Aplikasi Bisnis. Yogyakarta: Andi.

Judge, T. A., Thoresen, C. J., Bono, J. E., \& Patton, G. K. (2001). The job satisfaction-job performance relationship: A qualitative and quantitative review. Psychological Bulletin, 127(3), 376-401.

Lumley, E. J., Coetzee, M., Tlandiyane, R. and Ferreira, N. (2011). Exploring the job satisfaction and organisational commitment of employees in the information technology environment. Southern African Business Review, 15(1), 100-118.

Luthans, F. (1998). Organisational Behavior (2ed.). Boston: Irwin McGraw-Hill.

Luthans, F. (2008). Organisational Behavior: An Evidence-Based Approach (12 ed.). New York: Irwin Mcgraw-Hill.

Milliman, J., Czaplewski, A. J., \& Ferguson, J. (2003). Workplace spirituality and employee work attitudes: An exploratory empirical assessment. Journal of Organizational Change Management, 16(4), 426-447.

Muafi. (2011). Causes and consequence deviant workplace behavior. International Journal of Innovation, Management and Technology, 2(2), 123-126.

O'Leary-Kelly, A. M., Griffin, R. W. and Glew, D. J. (1996). Organization-motivated agression: A research framework. The Academy of Management Review, 21(1), 225-253.

Robbins, S. P. (1993). Organizational Behavior: Concepts, Controversies, and Application (6 ed.). New Jersey: Prentice-Hall.

Robbins, S. P. (2001). Organizational Behavior (11 ed.). New Jersey: Pearson Prentice-Hall.

Robbins, S. P. and Judge, T. A. (2015). Organizational Behavior. New York: Pearson Education Limited.

Srivastava, S. (2013). Job satisfaction and organizational commitment relationship: Effect of personality variables vision. The Journal of Business Perspective, 17(2), 159-167.

Tella, A., Ayeni, C. O. and Popoola, S. O. (2007). Work motivation, job satisfaction, and organizational commitment of Library Personnel in Academic and Research Libraries in Oyo State Nigeria. Library Philosophy and Practice, 118(1), 1-16.

Zigarmi, D., Houson, D., Witt, D. and Diehl, J. (2011). Employee work passion: Connecting the dots. Perspectives, pp. 1-10.

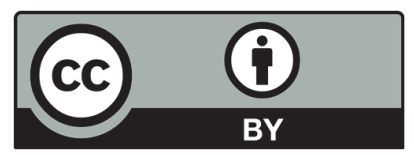

(C) 2020 by the authors; licensee Growing Science, Canada. This is an open access article distributed under the terms and conditions of the Creative Commons Attribution (CC-BY) license (http://creativecommons.org/licenses/by/4.0/). 